\title{
Measurement of radon exhalation rate in various building materials and soil samples
}

\author{
Pankaj Bala ${ }^{1, *}$, Vinod Kumar ${ }^{1}$ and Rohit Mehra ${ }^{2}$ \\ ${ }^{1}$ Department of Applied Sciences, Humanities and Management, Beant College of Engineering \\ and Technology, Gurdaspur, Punjab, India. \\ ${ }^{2}$ Department of Physics, Dr. B.R. Ambedkar National Institute of Technology, Jalandhar, Punjab, India. \\ *Corresponding author. e-mail: pankajbala.nitj@gmail.com
}

Indoor radon is considered as one of the potential dangerous radioactive elements. Common building materials and soil are the major source of this radon gas in the indoor environment. In the present study, the measurement of radon exhalation rate in the soil and building material samples of Una and Hamirpur districts of Himachal Pradesh has been done with solid state alpha track detectors, LR-115 type-II plastic track detectors. The radon exhalation rate for the soil samples varies from 39.1 to $91.2 \mathrm{mBq} \mathrm{kg}^{-1} \mathrm{~h}^{-1}$ with a mean value $59.7 \mathrm{mBq} \mathrm{kg}{ }^{-1} \mathrm{~h}^{-1}$. Also the radium concentration of the studied area is found and it varies from 30.6 to $51.9 \mathrm{~Bq} \mathrm{~kg}{ }^{-1}$ with a mean value $41.6 \mathrm{~Bq} \mathrm{~kg}^{-1}$. The exhalation rate for the building material samples varies from 40.72 (sandstone) to $81.40 \mathrm{mBq} \mathrm{kg}^{-1} \mathrm{~h}^{-1}$ (granite) with a mean value of $59.94 \mathrm{mBq} \mathrm{kg}^{-1} \mathrm{~h}^{-1}$.

\section{Introduction}

Radon is one of the potential dangerous radioactive elements in the environment. Radon enters into buildings through the soil or building materials. So radon exhalation rate from the soil or building material is an important parameter for estimating local environmental radon level. The concentration of radon and its decay products changes due to variations in various factors like temperature, pressure, building materials, ventilation conditions, etc. Therefore, it is necessary to have knowledge of the radium concentration and radon exhalation rate in soil and building materials, for accurate assessment of possible radiological hazards and risks to human health. The emission of radon per unit area per unit time is called exhalation rate and depends upon: (a) radium concentration in the material which in turn depends on the uranium concentration in the material, (b) emanation factor of radon from the material, (c) porosity and density of the material, and (d) diffusion coefficient of radon in the material. Radon gas ionizes the ambient atmospheres both indoor and outdoor. The exhalation of radon from soil involves two mechanisms, the emanation and transport. These mechanisms are affected by many factors including the properties of the soil (Munazza and Matiullah 2008). The half life of radium is 1600 years and that of radon is 3.82 days. So it has enough time to allow it to migrate through the soil and enter the atmosphere (Khan et al. 2011). Indoor radon has been recognized as one of the health hazards for mankind. Most building materials of natural origin contain small amounts of Naturally Occurring Radioactive Materials (NORM), mainly radionuclides from the ${ }^{238} \mathrm{U}$ and ${ }^{232} \mathrm{Th}$ decay chains, and ${ }^{40} \mathrm{~K}$. The worldwide average indoor effective dose due to gamma rays from building materials is estimated to be about $0.4 \mathrm{mSv}$ per year (UNSCEAR 2000).

Keywords. Radon; exhalation rate; dose; radium concentration. 
The natural radioactivity in building materials gives rise to internal and external radiation exposure. However, the internal radiation exposure mainly affecting the respiratory tract is caused by the short-lived daughter-products of radon, which are emitted from the construction material including the cement into the room air (Mustonen 1984). During respiration, radon progeny deposit in the lungs and irradiate the tissue, thereby damaging the cells, and may cause lung cancer (Mehra et al. 2006). However, elevated levels of natural radionuclides causing annual doses of several $\mathrm{mSv}$ were identified in some regions around the world, e.g., in Brazil, France, India, Nigeria, Iran. In India, there are certain regions where higher concentration of radon is found. The indoor radon values reported in some dwellings of Hamirpur $\left(660-1060 \mathrm{~Bq} \mathrm{~m}^{-3}\right.$, Kumar et al. (1994)), and Una (235-970 Bq m${ }^{-3}$, (Singh et al. 2002)) districts of Himachal Pradesh. The higher indoor radon values in these areas are explained due to the presence of uranium mineralization in the area (Kaul et al. 1993). Most of the indoor radon values lie in the range of action levels (200-400 $\mathrm{Bq} \mathrm{m}^{-3}$ ) recommended by International Commission on Radiological Protection. The materials that contain high concentration of NORM, have the potential to be carcinogenic when exposed to them (UNSCEAR 2000). According to Canadian Guidelines for the Management of Naturally Occurring Radioactive Materials (NORM), the average annual effective dose for occupationally exposed workers and incidentally exposed workers should not exceed 20 and $1 \mathrm{mSv}$, respectively. Also, the derived working limit for radon is $200 \mathrm{~Bq} \mathrm{~m}{ }^{-3}$. Unconditional derived release limits for Uranium-238, Thorium-232 and Potassium-40 is $10,000,10,000$ and $17,000 \mathrm{Bg} \mathrm{kg}^{-1}$, respectively.

Therefore, monitoring of the radioactive materials in environmental samples is of primary importance from the view point of radiation protection of the environment. Various soil samples and common building materials used for construction of houses, which are considered as major source of radon gas in indoor environment, have been studied for exhalation rate of radon (Schery et al. 1989; El-Bahi 2004; Bollhöfer et al. 2006). Since the soils have generally about $10^{3}-10^{4}$ times gas concentrations than in the atmosphere, there is always a concentration gradient present which is maintained by the continuous decay of radioactive elements. Commonly used earth-based building materials, like bricks, sand, cement, etc., also contain uranium and thorium in varying amounts. The radioactive gases produced in these materials due to decay of ${ }^{226} \mathrm{Ra}$ and ${ }^{224} \mathrm{Ra}$ are also transported to indoor air through diffusion and convective flow. However, only a fraction of the radon generated in a material is able to escape to the atmosphere. The soil and building materials are considered as mainly responsible for indoor concentration as other sources generally contribute only a fraction of total indoor activity. There are many factors that affect the exhalation rate from a surface, e.g., atmospheric pressure, rainfall, humidity and temperature. It is well known that the most important source of external and internal exposure in building materials of dwellings is caused by gamma-rays and alpha-particles emitted from radionuclides of the uranium $\left({ }^{238} \mathrm{U}\right)$ and thorium $\left({ }^{232} \mathrm{Th}\right)$ decay series as well as from ${ }^{40} \mathrm{~K}$ (Maged and Borham 1997; Zaidi et al. 1999; Farai and Ademola 2005; Ademola 2008). Radon and thoron are both generated from radium isotopes decay in the solid grains. Both emanated to pore gases or fluids and then migrated to a significant distance from the site of generation in rock, soil and/or building materials into the atmosphere (exhalation) before undergoing radioactive decay.

\section{Geology of the study area}

Hamirpur (figure 1) and Una (figure 2) districts of Himachal Pradesh are selected as sampling sites for the research work. The soil found in the districts of Una and Hamirpur is generally brown, alluvial and grey brown. Himachal Pradesh is blessed with mineral wealth. As per the investigation of Geological Survey of India, minerals available in Himachal Pradesh include limestone, clays, mica, iron pyrites, salt, gypsum, slate, antimony and lead. The geographical description of the districts of Hamirpur and Una is as follows.

Hamirpur district is situated between $76^{\circ} 18^{\prime}-$ $76^{\circ} 44^{\prime} \mathrm{E}$ longitudes and $31^{\circ} 25^{\prime}-31^{\circ} 52^{\prime} \mathrm{N}$ latitudes. It is located in the southwestern part of Himachal Pradesh. It is covered by lower Himalayas; the elevation varies from 400 to $1100 \mathrm{~m}$. The middle and upper Shivalik and the comparatively recent deposits constitute the main geological formations. The Shivalik comprises of sandstones, siltstone, clay stone, granites, quartzite and pebbles. Hamirpur district is bounded in the north by river Beas which separates it from Kangra district. In the east, Bakar and Seer Khads separate it from Mandi district. In the south, it is bounded by Bilaspur district and in the west by Una district.

Una lies within latitude $31^{\circ} 17^{\prime} 52^{\prime \prime}-31^{\circ} 52^{\prime} 0^{\prime \prime} \mathrm{N}$ and longitude $75^{\circ} 58^{\prime} 2^{\prime \prime}-76^{\circ} 28^{\prime} 25^{\prime \prime} \mathrm{E}$. Una is in the southwestern part of Himachal Pradesh bounded by Kangra, Hamirpur and Bilaspur districts of Himachal Pradesh in the north, east and south, respectively and by Hoshiarpur district of Punjab in the west. Una district covers an area of $1549 \mathrm{~km}^{2}$ in Himalayan foothill zone bounded by plains of Punjab in the west and Solah Singhi Dhar in the 


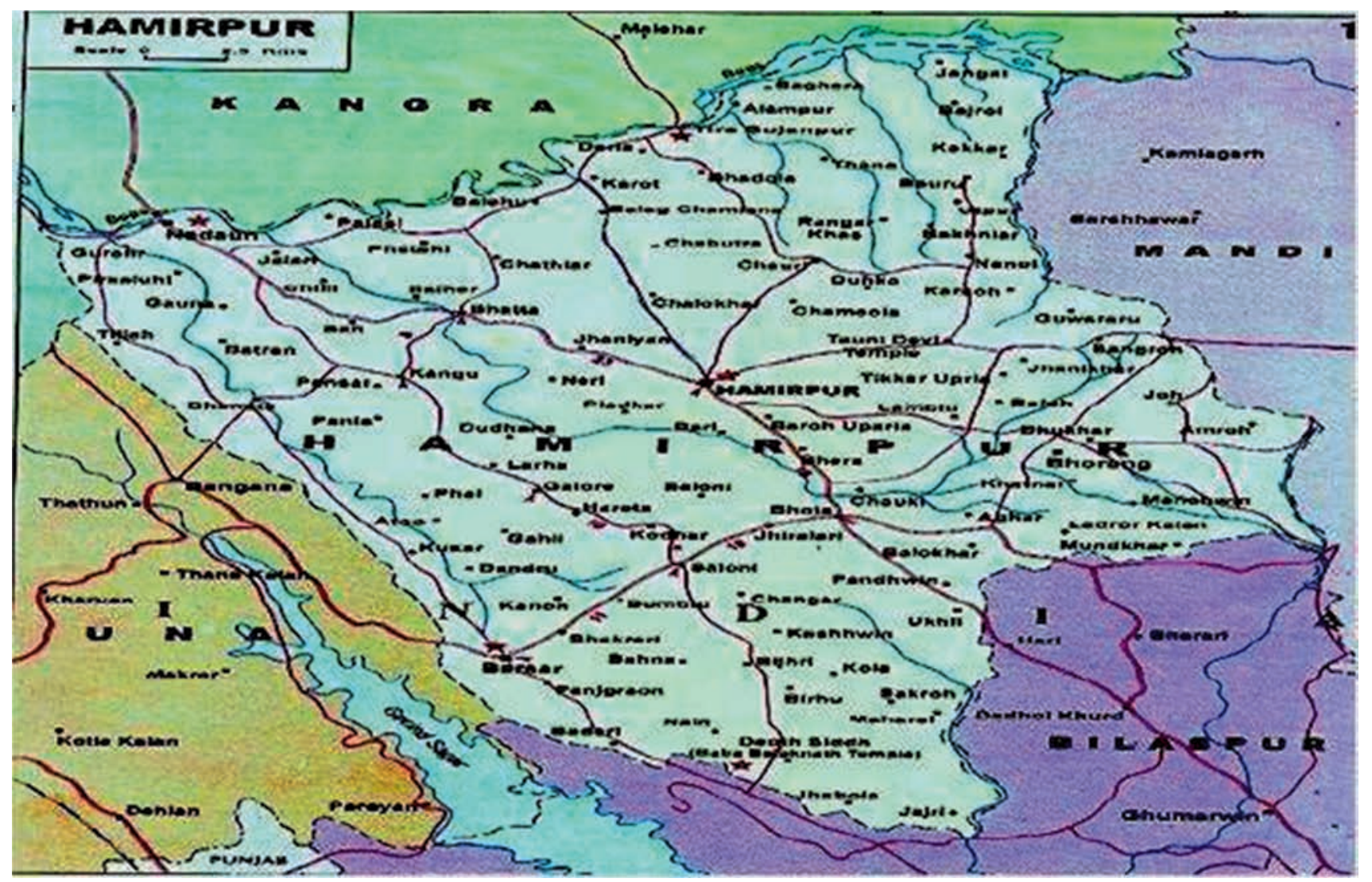

Figure 1. Map of Hamirpur district of Himachal Pradesh.

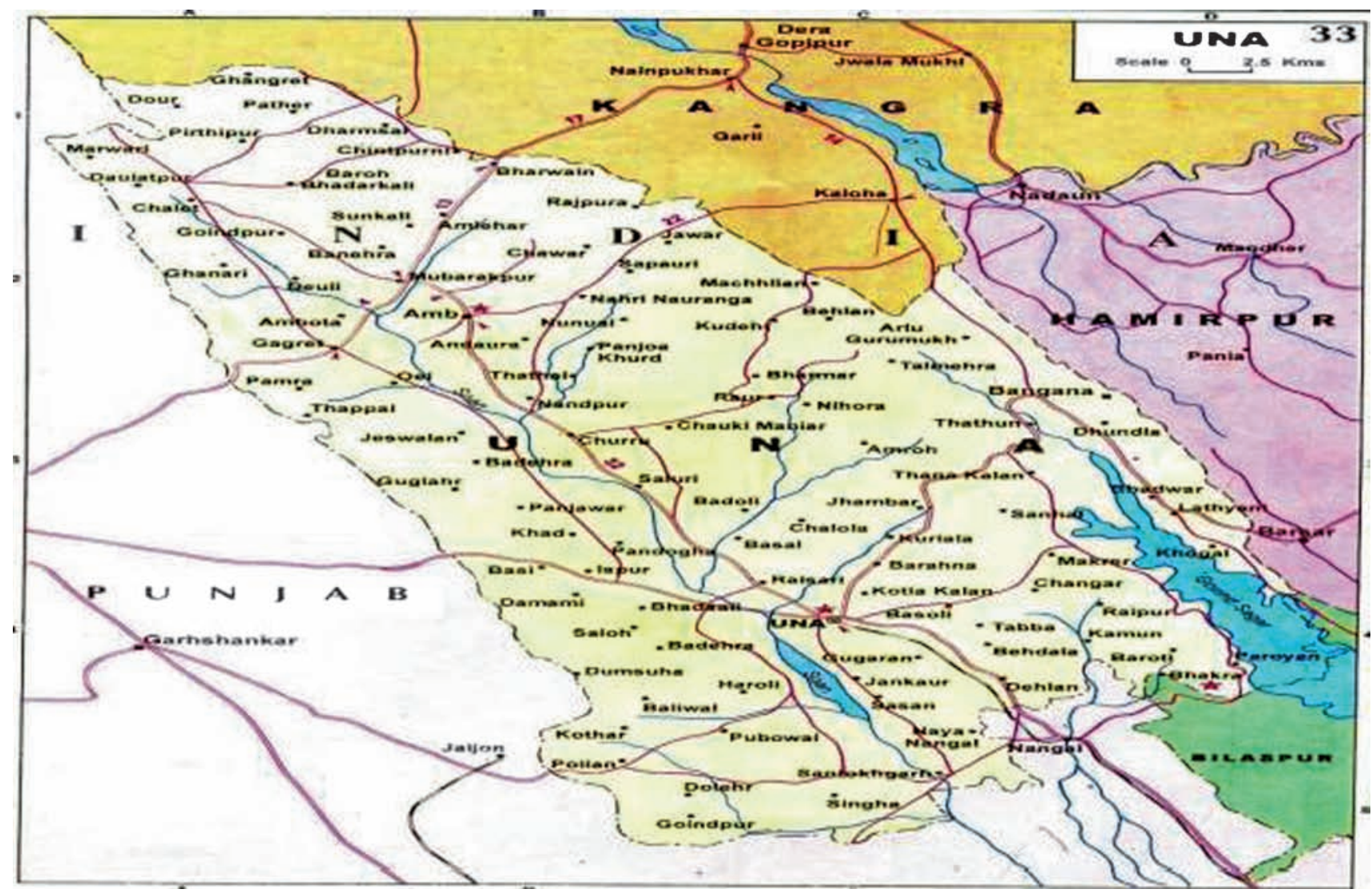

Figure 2. Map of Una district of Himachal Pradesh. 
east. The Una district has unique identity by having both plain areas and hilly areas. Alluvial fans, river terraces and gravel beds of recent age and the sandstone, clay stone and conglomerates belonging to Shivalik group are the main formations in this area. Recent deposits constitute gravel beds, alluvial fans and river terraces. Alluvium occupies the vast stretch of the plain. They contain sand, silt and clay in varying proportions.

\section{Materials and methods}

For the measurement of radon exhalation rate in the soil and building material samples, Closed Can Technique has been used. The soil samples are collected in clean, dry polyethylene bags from different locations of Una and Hamirpur districts of Himachal Pradesh, India. The soil is collected from an auger hole at a depth of about $0.75 \mathrm{~m}$ from the ground so as to get the natural soil. After collection, samples are crushed into fine powder using a mortar and pestle. A fine quality of the sample is obtained using a scientific sieve with a 150 micron mesh size. Before measurement, samples are dried in an oven at about $383 \mathrm{~K}$ for $24 \mathrm{hrs}$. Each sample is packed and sealed in an airtight PVC container and kept for about a four-week period to allow radioactive equilibrium between radon $\left({ }^{222} \mathrm{Rn}\right)$, thoron $\left({ }^{220} \mathrm{Rn}\right)$, and their short-lived progenies. On an average, $0.25 \mathrm{~kg}$ of soil is taken for each sample.

After one month, the bottles are opened and LR115 type-II plastic track detectors $(1 \mathrm{~cm} \times 1 \mathrm{~cm})$ are suspended inside the bottles in a bare mode. LR115 detector film mainly detects the alpha particles having energy ranging from 1.7 to $4.8 \mathrm{MeV}$. The height of the detector is selected such that direct alpha particles do not reach the detectors. The bottles are then closed for about one month to record alpha activity under secular equilibrium conditions (Shanbag et al. 2005). After exposure, the detectors are removed and etched in $2.5 \mathrm{~N} \mathrm{NaOH}$ solution at $60^{\circ} \mathrm{C}$ for $90 \mathrm{~min}$, using a constant temperature bath to develop the clear tracks of alpha particles on the detector films. The tracks are counted using an Olympus microscope at a magnification of 400. The resulting track density is then converted into $\mathrm{Bq} \mathrm{m}^{-3}$ by appropriate calibration factor of 0.02 tracks $\mathrm{cm}^{-2}$ day $^{-1}$ (Eappen et al. 2001). Now to calculate the radon exhalation rate in terms of mass (mBq kg ${ }^{-1} \mathrm{hr}^{-1}$ ) (Abu-Jarad et al. 1980):

$$
E_{M}=\frac{C V \lambda}{T_{e} M}
$$

where $E_{M}$ is the radon exhalation rate in terms of mass $\left(\mathrm{mBq} \mathrm{kg} \mathrm{kg}^{-1} \mathrm{hr}^{-1}\right), M$ is the the mass of the sample $(0.25 \mathrm{~kg}), T_{e}$ is the $T-1 / \lambda\left(1-\mathrm{e}^{(-\lambda t)}\right)$, effective exposure time, $C$ is the integrated radon exposure $\left(\mathrm{Bq} \mathrm{m}^{-3} \mathrm{hr}\right), V$ is the effective volume of the bottle $\left(\mathrm{m}^{3}\right), \lambda$ is the decay constant for radon $\left(\mathrm{hr}^{-1}\right)$ and $T$ is the exposure time (hr).

Radium concentration is calculated as (AbuJarad et al. 1980)

$$
C_{\text {radium }}=\frac{\rho h A}{K T_{e} M}
$$

where $C_{\text {radium }}$ is the effective radium content of soil sample $\left(\mathrm{Bq} \mathrm{kg}^{-1}\right), \rho$ is the track density, $A$ is the area of cross-section of the bottle, $h$ is the distance between the detector and the top of the soil sample, $K$ is the sensitivity factor, and $T_{e}$ is the effective exposure time.

\section{Results and discussion}

Table 1 shows radon mass exhalation rate, emanation coefficient of radon and alpha dose equivalent in soil samples of the studied area. The radon exhalation rate in the soil samples from the different locations of the Una and Hamirpur districts

Table 1. Radon mass exhalation rate and radium concentration of soil samples of Una and Hamirpur districts of Himachal

\begin{tabular}{|c|c|c|c|}
\hline Sl. no. & $\begin{array}{l}\text { Sample location } \\
\text { (Village) }\end{array}$ & $\begin{array}{c}\text { Radon mass } \\
\text { exhalation rate } \\
\left(\mathrm{mBq} \mathrm{kg}^{-1} \mathrm{~h}^{-1}\right)\end{array}$ & $\begin{array}{c}\text { Radium } \\
\text { concentration } \\
\left(\mathrm{Bq} \mathrm{kg}^{-1}\right)\end{array}$ \\
\hline \multicolumn{4}{|c|}{ Hamirpur } \\
\hline 1 & Garli & 48.9 & 39.7 \\
\hline 2 & Bijhari & 52.1 & 31.7 \\
\hline 3 & Dandroo & 68.4 & 33.4 \\
\hline 4 & Barsar & 57.0 & 39.0 \\
\hline 5 & Bhota & 48.9 & 30.6 \\
\hline 6 & Kangoo & 42.3 & 35.7 \\
\hline 7 & Nadaun & 58.6 & 37.9 \\
\hline 8 & Rangas & 81.4 & 41.1 \\
\hline 9 & Salouni & 40.7 & 36.1 \\
\hline 10 & Taunidevi & 79.8 & 30.9 \\
\hline \multicolumn{4}{|l|}{ Una } \\
\hline 11 & Jowar & 91.2 & 51.9 \\
\hline 12 & Lohara & 65.2 & 50.8 \\
\hline 13 & Daulatpur & 48.9 & 45.5 \\
\hline 14 & Gagret & 57.0 & 46.2 \\
\hline 15 & Oela & 48.9 & 37.4 \\
\hline 16 & Panjawar & 42.3 & 48.7 \\
\hline 17 & Saloh & 58.6 & 42.8 \\
\hline 18 & Haroli & 81.4 & 49.4 \\
\hline 19 & Kuriala & 73.3 & 50.1 \\
\hline 20 & Kotlakala & 53.8 & 46.6 \\
\hline 21 & Bangana & 58.6 & 46.3 \\
\hline 22 & Chowkimanyar & 65.2 & 48.0 \\
\hline 23 & Malangar & 39.1 & 36.4 \\
\hline 24 & Thathal & 66.8 & 43.1 \\
\hline 25 & $\mathrm{Amb}$ & 63.5 & 42.0 \\
\hline
\end{tabular}
Pradesh. 
of Himachal Pradesh are calculated. The radon exhalation rate is calculated in terms of mass $\left(E_{M}\right)$. The value of $E_{M}$ varies from 39.1 to $91.2 \mathrm{mBq}$ $\mathrm{kg}^{-1} \mathrm{~h}^{-1}$ with a mean value $59.7 \mathrm{mBq} \mathrm{kg}{ }^{-1} \mathrm{~h}^{-1}$. Also, the radium concentration of the studied area is found and it varies from 30.6 to $51.9 \mathrm{~Bq} \mathrm{~kg}^{-1}$ with a mean value $41.6 \mathrm{~Bq} \mathrm{~kg}^{-1}$.

The results show that there is a variation in radon exhalation rate from one location to other which depends on the geological formation. The variation in values of radon exhalation rate may be due to the differences in radium content (Ramachandran and Subba Ramu 1989) and porosity (Folkerts et al. 1984) of the soil. The present values of the radon exhalation rate observed in the soil are generally low as compared to the values reported for the soils of Kangra, Himachal Pradesh (Sharma et al. 2003). When comparison is made, it is found that the present value of radon exhalation rate is lower than that of the values of the soil of Iraqi Kurdistan (Ismail and Jaafar 2010). Table 2 shows radon mass exhalation rate, emanation coefficient of radon and alpha dose equivalent in building material samples. The building materials selected for the study are sandstone, marble, granite and cement samples. From the table, it is seen that the exhalation rate for the building material samples varies from 40.72 (sandstone) to $81.40 \mathrm{mBq} \mathrm{kg} \mathrm{k}^{-1} \mathrm{~h}^{-1}$ (granite) with a mean value of $59.94 \mathrm{mBq} \mathrm{kg} \mathrm{h}^{-1}$. From the results, it is clear that granite sample shows higher radon exhalation rate than that of marble and sandstone samples. It can be seen from the results that the radon exhalation rate and radium concentration varies appreciably in various samples. It is due to the fact that the soil and building material samples collected from various sites may have appreciably large uranium contents which results in higher radon emanation rates (Bahi El 2004). The values of effective radium content are less than the permissible value of $370 \mathrm{~Bq} \mathrm{~kg}{ }^{-1}$ as recommended by Organization for Economic Cooperation and Development (OECD 1979). Hence, the result shows that this study area is safe as far as the health hazards of radium are concerned. It is recommended that the radon exhalation rate should be measured for all building materials and a standard code placed on all products. This will minimize the indoor radon concentration in new construction, especially in new locations. Figures 3 and 4 show the error bar graph of the distribution of radon mass exhalation rate and radium concentration in the soil of the studied area. From these figures, it is shown that the highest radon concentration is found in Una district. This may be due to the reason that the Hamirpur district is a hilly area and mud construction is most common for the houses in this area, but Una district is a bit developed area having concrete construction.

\section{Emanation coefficient for radon}

A fraction of ${ }^{222} \mathrm{Rn}$ which diffused through the building materials is known as the emanation coefficient of the material. The emanation coefficient of radon can be considered as an important radiological index used to evaluate the amount of ${ }^{222} \mathrm{Rn}$ released from cement samples (Turhan 2008). The radon emanation coefficient can be expressed as:

$$
f=E_{m} / A_{\mathrm{R}} \lambda,
$$

where $f$ is the radon emanation coefficient, $E_{m}$ is the radon mass exhalation rate $\left(\mathrm{Bq} \mathrm{kg}^{-1} \mathrm{~h}^{-1}\right), A_{\mathrm{R}}$ is the radium concentration $\left(\mathrm{Bq} \mathrm{kg}^{-1}\right)$ and $\lambda$ is ${ }^{222} \mathrm{Rn}$ decay constant $\left(\mathrm{s}^{-1}\right)$. In building materials,

Table 2. Radon mass exhalation rate, emanation coefficient of radon and alpha dose equivalent in building material samples.

\begin{tabular}{cccccc}
\hline Sl. no. & Sample & $\begin{array}{c}\text { Radon mass } \\
\text { exhalation rate } \\
\left(\mathrm{mBq} \mathrm{kg}^{-1} \mathrm{~h}^{-1}\right)\end{array}$ & $\begin{array}{c}\text { Radium } \\
\text { concentration } \\
\left(\mathrm{Bq} \mathrm{kg}^{-1}\right)\end{array}$ & $\begin{array}{c}\text { Alpha dose } \\
\text { Emanation } \\
\text { coefficient }(\%)\end{array}$ & $\begin{array}{c}\text { equivalent } \\
\left(\mathrm{mSv} \mathrm{yr}^{-1}\right)\end{array}$ \\
\hline 1 & M-1 & 66.78 & 31.90 & 27.69 & 7.97 \\
2 & G-1 & 71.67 & 45.30 & 20.93 & 8.55 \\
3 & S-1 & 48.86 & 30.20 & 21.40 & 5.84 \\
4 & M-2 & 57.01 & 43.60 & 17.30 & 6.81 \\
5 & G-2 & 70.04 & 45.20 & 20.50 & 8.36 \\
6 & M-3 & 53.75 & 39.70 & 17.91 & 6.42 \\
7 & M-4 & 58.64 & 44.60 & 17.39 & 7.00 \\
8 & S-2 & 40.72 & 24.70 & 21.81 & 4.87 \\
9 & S-3 & 50.49 & 38.20 & 17.48 & 6.03 \\
10 & G-3 & 81.40 & 49.80 & 21.62 & 9.71 \\
\hline
\end{tabular}

Note: S-1, S-2, S-3 = sandstone samples; M-1, M-2, M-3, M-4 = marble samples and G-1, G-2, G-3 = granite samples. 


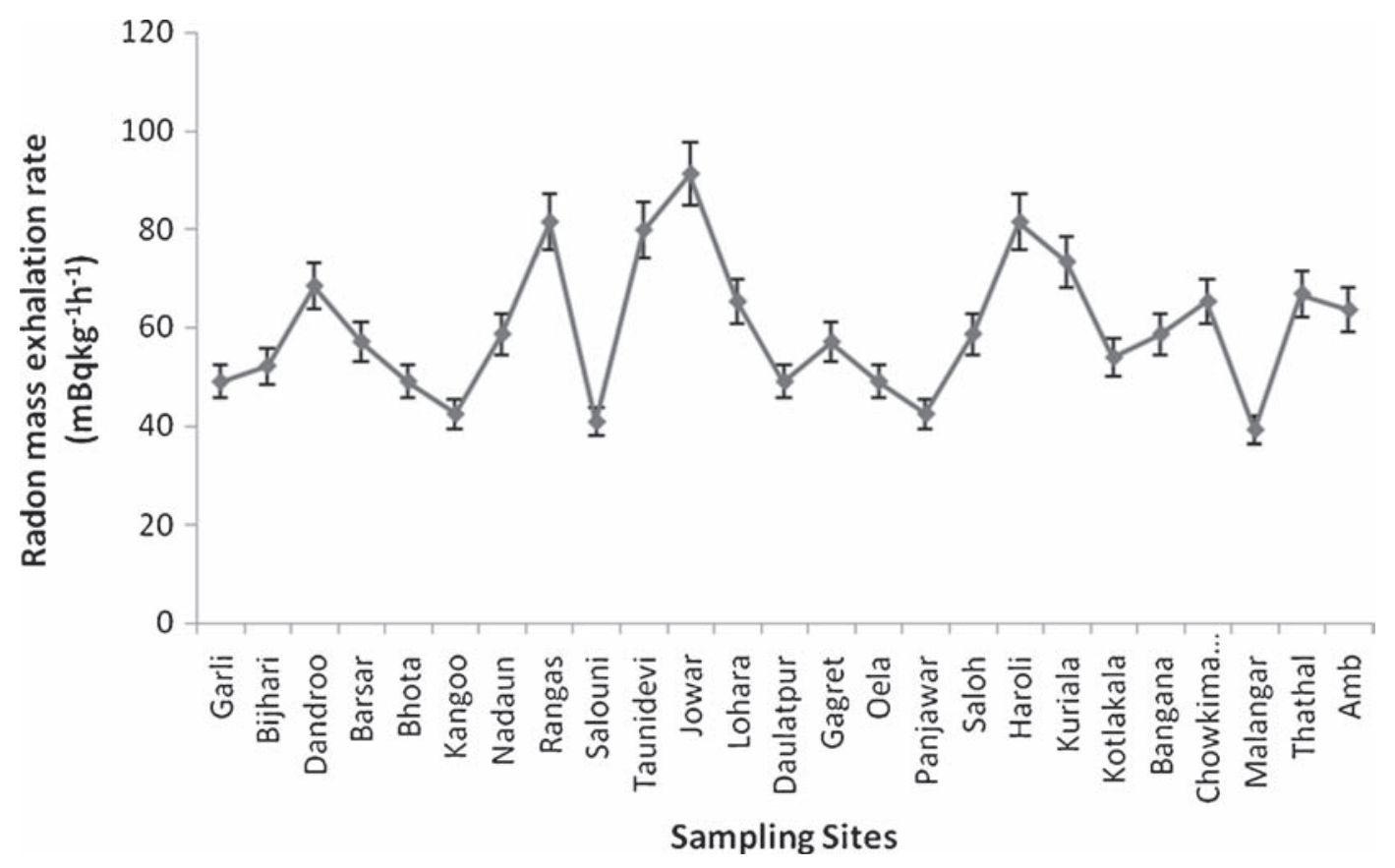

Figure 3. Error bar graph showing the distribution of radon mass exhalation rate in the study area.

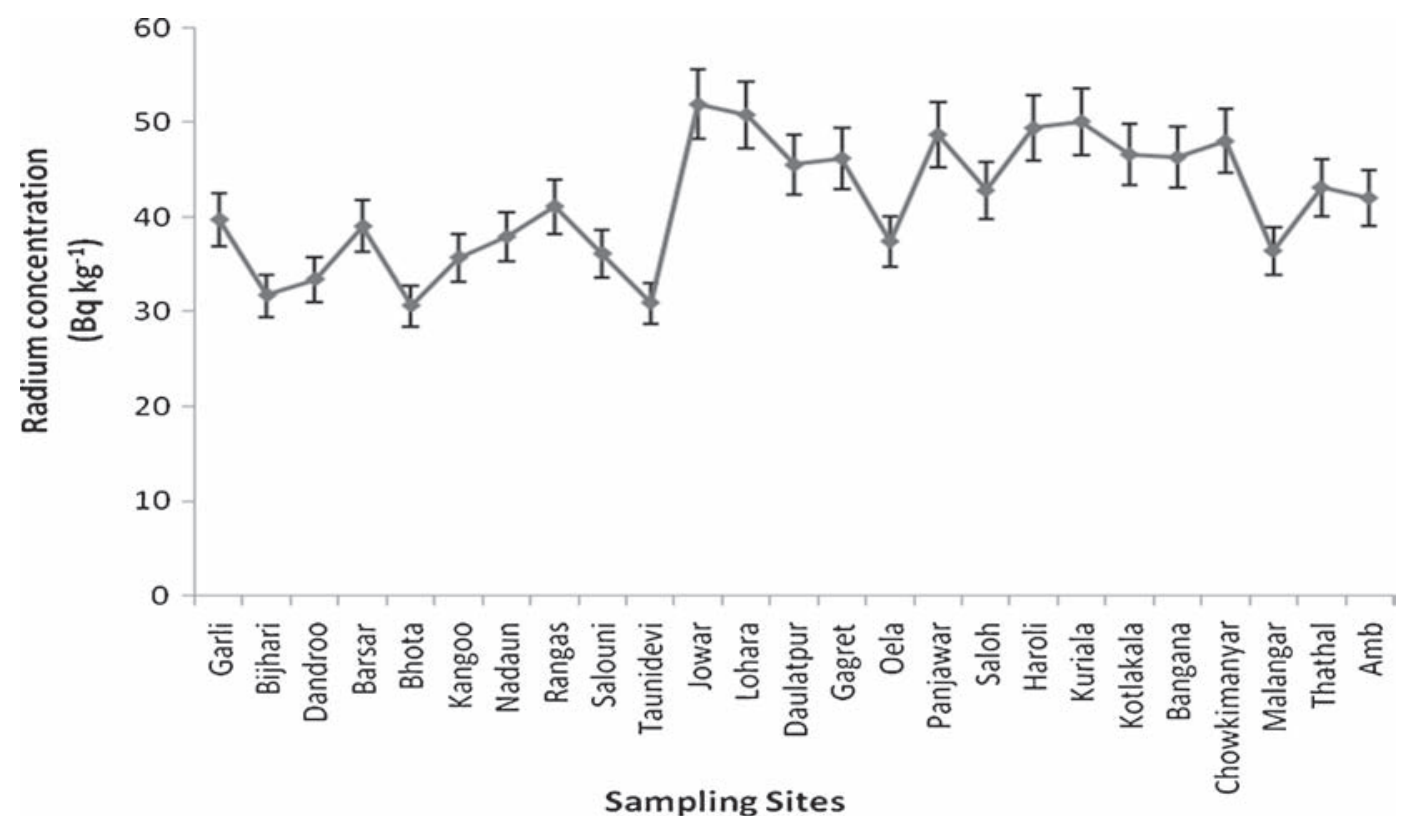

Figure 4. Error bar graph showing the distribution of radium concentration in the study area.

emanation coefficient of radon varies from $17.30 \%$ to $27.69 \%$, but in cement samples, it varies from $7.13 \%$ to $18.10 \%$.

\section{Alpha dose equivalent}

The level of the alpha dose attributable to the presence of radon and its short-lived daughters of radon $\left({ }^{222} \mathrm{Rn}\right)$ in air play a significant role, while calculating exposure to radon. Recent studies have shown that dose due to radon found in dwellings may be readily correlated to radon concentration itself rather than radon and its progeny. The Commission of European Communities report (CEC 1990) recommends that conversion factor of $1 \mathrm{~Bq}$ $\mathrm{m}^{-3}$ from radon $\left({ }^{222} \mathrm{Rn}\right)$ corresponds to an effec-

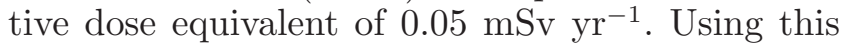
conversion factor, it is possible to calculate the alpha dose (Bruzzi et al. 1992) using specific 
activity of ${ }^{226} \mathrm{Ra}$, on the hypothesis of secular equilibrium which is equal to that of ${ }^{238} \mathrm{U}$. The effective alpha dose equivalent, $H_{E}\left(\mathrm{mSv} \mathrm{yr}^{-1}\right)$ can be expressed as:

$$
H_{E}=0.18 f A_{\mathrm{Ra}}+0.45
$$

where $f$ is the emanation coefficient and $A_{\mathrm{Ra}}$ is the radium specific radioactivity in materials. Table 2 shows the effective alpha dose equivalent for the building material samples and it varies from 4.87 (sandstone) to $9.71 \mathrm{mSv} \mathrm{yr}^{-1}$ (granite) with a mean value of $7.16 \mathrm{mSv} \mathrm{yr}^{-1}$.

\section{Conclusion}

The value of radon mass exhalation rate varies from 39.1 to $91.2 \mathrm{mBq} \mathrm{kg}^{-1} \mathrm{~h}^{-1}$ with a mean value of $59.7 \mathrm{mBq} \mathrm{kg}^{-1} \mathrm{~h}^{-1}$. Also the radium concentration of the studied area varies from 30.6 to $51.9 \mathrm{~Bq} \mathrm{~kg}^{-1}$ with a mean value of $41.6 \mathrm{~Bq} \mathrm{~kg} \mathrm{~kg}^{-1}$. There is a variation in radon exhalation rate from one location to other which depends on the geological formation. Granite samples show higher radon exhalation rate than that of marble and sandstone samples. It is recommend that the radon exhalation rate should be measured for all building materials and a standard code placed on all products. This will minimize the indoor radon concentration in new construction, especially in new locations. The values of effective radium content are less than the permissible value of $370 \mathrm{~Bq} \mathrm{~kg}^{-1}$ as recommended by Organization for Economic Cooperation and Development (OECD 1979). Hence, the result shows that this study area is safe as far as the health hazards of radium are concerned.

\section{Acknowledgements}

The authors are thankful to the residents of the study area for their cooperation during the sample collection, and to the Department of Physics, NIT, Jalandhar, for providing us the research facilities at their laboratories.

\section{References}

Abu-Jarad F, Fremlin J H and Bull R 1980 A study of radon emitted from building materials using plastic track detectors; Phys. Med. Biol. 25(4) 683-694.

Ademola J A 2008 Determination of natural radionuclides content in some building materials in Nigeria by gammaray spectrometry; Health Phys. 94 43-48.

Bahi El SM 2004 Assessment of radioactivity and radon exhalation rate in Egyptian cement; Health Phys. 86 $517-522$.
Bollhöfer A, Storm J, Martin P and Tims S 2006 Geographic variability in radon exhalation at a rehabilitated uranium mine in the northern territory, Australia; Environ. Monit. Assess. 114 313-330.

Bruzzi L, Mele R and Padoani F 1992 Evaluation of gamma and alpha doses due to natural radioactivity of building materials; J. Radiol. Prot. 12 67-76.

CEC 1990 Recommendation de la Commission Relative a la Protection de la Population Contre les Dangers Resultant de l'Exposition au Radon a l'Interieur des Batiments; Commission des Communautes Europeennes, Brussels.

Eappen K P, Ramachandran T V, Shaikh A N and Mayya Y S 2001 Calibration factor for SSNTD-based radon/ thoron dosimeters; Radiat. Protect. Environ. 24(1-2) 410-414.

El-Bahi S M 2004 Assessment of radioactivity and radon exhalation rate in Egyptian cement; Health Phys. 86 $517-522$.

Farai I P and Ademola J A 2005 Radium equivalent activity concentrations in concrete building blocks in eight cities in southwestern Nigeria; J. Environ. Radioact. 79 $119-125$.

Folkerts K H, Keller G and Muth R 1984 An experimental study of diffusion and exhalation of ${ }^{222} \mathrm{Rn}$ and ${ }^{220} \mathrm{Rn}$ from building materials; Radiat. Prot. Dosim. 9 27-34.

Ismail A H and Jaafar M S 2010 Hazards assessment of radon exhalation rate and radium content in the soil samples in Iraqi Kurdistan using passive and active detecting methods; World Acad. Sci. Eng. Technol. 70 701-704.

Kaul R, Umamaheshwar K, Chandrasekaram S, Deshmukh R D and Swarnkar B M 1993 Uranium mineralization in the Siwalik of northwestern Himalaya, India; J. Geol. Soc. India 41 243-258.

Khan M S, Naqvi A H, Azam A and Srivastava D S 2011 Radium and radon exhalation studies of soil; Iran J. Radiat. Res. 8(4) 207-210.

Kumar J, Malhotra R, Singh J and Singh S 1994 Radon measurements in dwellings in radioactive areas in Himachal Pradesh, India, using LR-115, plastic track detectors; Nucl. Geophys. 8(6) 573-576.

Maged A F and Borham E 1997 A study of the radon emitted from various building materials using alpha track detectors; Radiat. Meas. 28 613-617.

Mehra R, Singh S and Singh K 2006 A study of uranium, radium, radon exhalation rate and indoor radon in the environs of some areas of the Malwa region, Punjab; Indoor Built Environ. 15 499-505.

Munazza F and Matiullah 2008 Radon exhalation and its dependence on moisture content from samples of soil and building materials; Radiat. Meas. 43 14581462.

Mustonen R 1984 Natural radioactivity in and radon exhalation from Finnish building materials; Health Phys. 46 1195-1203.

Organization for Economic Cooperation and Development (OECD) 1979 Exposure to radiation from natural radioactivity in building materials. Report by a group of Experts of the OECD Nuclear Energy Agency; OECD, Paris.

Ramachandran T V and Subba Ramu M C 1989 Estimation of indoor radiation exposure from the natural radioactivity content of building materials; Oncol. 3 20-25.

Schery S D, Whittlestone S, Hart K P and Hill S E 1989 The flux of radon and thoron from Australian soils; J. Geophys. Res. 94 8567-8576. 
Shanbag A A, Sartandel S J, Ramachandran T V and Puranik V D 2005 Natural radioactivity concentrations in beach sands of Ratnagiri coast, Maharastra; J. Assoc. Environ. Geochem. 8 304-308.

Sharma D K, Kumar A, Kumar M and Singh S 2003 Study of uranium, radium and radon exhalation rate in soil samples from some areas of Kangra district, Himachal Pradesh, India using solid state nuclear track detectors; Radiat. Meas. 36 363-366.

Singh S, Kumar A and Singh B 2002 Radon level in dwellings and its correlation with uranium and radium content in some areas of Himachal Pradesh, India; Environ. Int. 28 97-101.
Turhan S 2008 Assessment of the natural radioactivity and radiological hazards in Turkish cement and its raw materials; J. Environ. Radioact. 99 404-414.

United Nations Scientific Committee on the Effects of Atomic Radiation 2000 Sources and Effects of Ionizing Radiation; New York.

Zaidi J H, Arif M, Ahmad S, Fatima I and Qureshi I H 1999 Determination of natural radioactivity in building materials used in Rawalpindi/Islamabad area by $\gamma$-ray spectrometry and instrumental neutron activation analysis; Appl. Radiat. Isot. 51 559564.

MS received 18 May 2016; revised 11 November 2016; accepted 15 November 2016

Corresponding editor: K KRISHNAMOORTHY 